\title{
A LEARNING MODEL OF BAHASA INDONESIA AS A FOREIGN LANGUAGE BASED ON LOCAL INTERCULTURAL POLITENESS
}

\author{
Gusnawaty Gusnawaty*, dan Andi Nurwati \\ Hasanuddin University Makassar, State Institute of Islamic Studies (IAIN) Sultan Amai \\ Gorontalo, Indonesia \\ *e-mail: nurwati.andin@iaingorontalo.ac.id
}

\begin{abstract}
The study was aimed for developing a learning model of Bahasa Indonesia based on local intercultural politeness to improve the foreigners' communicative competencies. This is Research and Development, started with a preliminary study of intercultural learning concepts and Buginese politeness strategies; the distribution of the needs analysis instruments to the 25 foreigners learning Bahasa Indonesia in Makassar, South Sulawesi, Indonesia; model development, focus group discussions; the model finalization and product experiment. The interviews and questionnaires data were analyzed by descriptive quantitative and qualitative. The result, a local politeness intercultural learning model consisting of four phases: noticing, comparing, reflecting, and interacting. 1) The foreign learners noticed the use of local politeness markers in Bahasa Indonesia; 2) They compared the similarities and differences between the use of the markers of local politeness and those they found in their native languages; 3) They reflected themselves; 4) They practiced Bahasa Indonesia through direct interactions. The conclusion showed that the $\mathrm{t}$-score $=3.26>\mathrm{t}$-table $=2.45$ signifying that the model was effective in overcoming the foreign learners' problems in oral interactions and improving their Bahasa Indonesia communicative competencies.
\end{abstract}

\section{Keywords: learning model, local politeness, intercultural, Bahasa Indonesia, Bugis Language}

\section{MODEL PEMBELAJARAN BAHASA INDONESIA SEBAGAI BAHASA ASING BERBASIS KESANTUNAN LOKAL ANTARBUDAYA}

\begin{abstract}
Abstrak: Penelitian ini bertujuan mengembangkan model pembelajaran bahasa Indonesia berbasis kesantunan lokal antarbudaya untuk meningkatkan kompetensi komunikatif penutur asing. Penelitian pengembangan ini dimulai dari studi awal terhadap konsep pembelajaran antarbudaya dan strategi kesantunan Bugis; penyebaran instrumen analisis kebutuhan kepada 25 penutur asing yang sedang belajar di Makassar, Sulawesi Selatan, Indonesia; pengembangan model; diskusi kelompok terpadu; finalisasi model dan uji coba produk. Data hasil wawancara dan kuestioner dianalisis dengan deskriptif kualitatif dan kuantitatif. Hasil penelitian adalah suatu model pembelajaran kesantunan lokal antarbudaya terdiri dari empat tahapan, yaitu memerhatikan, membandingkan, merekfleksikan, dan berinteraksi. 1) Penutur asing memerhatikan penggunaan pemarkah kesantunan lokal dalam bahasa Indonesia melalui media teks tulis dan/atau audio visual; 2) Membuat perbandingan, berupa persamaan dan perbedaan penggunaan pemarkah kesantunan lokal dalam bahasa Indonesia dengan apa yang ada dalam bahasa asli mereka; 3) Mempresentasikan refleksi diri terhadap hal yang dibahas; 4) Mempraktikkan bahasa Indonesia melalui interaksi langsung dengan masyarakat di tempat-tempat umum. Hasil analisis menunjukkan t-statistik cukup signifikan, artinya model ini efektif mengatasi masalah penutur asing dalam menggunakan pemarkah kesantunan lokal dalam interaksi lisan serta meningkatkan kompetensi komunikatif bahasa Indonesia.
\end{abstract}

Kata Kunci: model pembelajaran, kesantunan lokal, antarbudaya, Bahasa Indonesia, Bahasa Bugis 


\section{INTRODUCTION}

Recently, Bahasa Indonesia has been regarded as a favourite language among foreign people due to many reasons. Among them are tourism, business, investment, and work (Sudini, 2008). This is because Indonesia has many beautiful places and islands and many kinds of unique cultures and traditions. There are many natural resources and the Indonesian government is open to accept investors from other countries to open their businesses here. Moreover, Indonesia is a member of the Asian Economic Community (MEA), which means that workers from Asian countries can apply for jobs in companies in Indonesia. For having such a job, the Indonesian government requires foreign workers to have the skill to speak Indonesian as mandated by Article 33 paragraph (2) of Law Number 24 of 2009 about Flag, Language, and National Symbol, as well as National Anthem (RoI, 2009).

Based on those reasons above, there are 72 countries all over the world in which Indonesian is formally taught, such as Maroko, Jerman, Polandia, Australia, USA, Canada, Vietnam, Korea, Thailand and many other countries (Sari, Sutama, \& Utama, 2016). As an example, in Australia, Indonesian become the fourth most popular language. Bahasa Indonesia is taught in 500 schools. The children of $6^{\text {th }}$ grade elementary school have been able to speak Indonesian (Andayani, 2016).

The increasing interest in learning Indonesian has heightened the need for developing new methods and teaching materials of Teaching Bahasa Indonesia as a Foreign Language (TISOL). Those can be effective to improve communicative competence for the foreign learners. Several researchers for example of teaching material development. Megawati (2014) developed a learning media of intermediate BIPA through an interactive e-book and Karim (2015) developed a text-book. Responding to the development of information technology-based learning media, Siroj (2015) developed a model of integrated BIPA's ICT based-learning materials of socio-cultural domains for foreign learners' fluency in speaking. Meanwhile, Bagus utilized foreign speakers' needs in developing certain teaching materials and learning methods (Bagus, Mantra, Ayu, Sri, \& Author, 2017). One of the foreign speakers need is an interesting topic of materials. In various aspects of learning, the topic of learning will support the implementation of the class to be good or conversely (Kusmiatun, 2016). Literature is an interesting topic that contains moral and or values of forming attitudes and behavior (Nurgiyantoro, 2010). Using literature as a teaching material for foreign speakers to introduce Indonesian culture (Nurhuda, Waluyo, \& Suyitno, 2017).

Learning methods for BIPA had been developed by many researchers such as, Andayani (2016) developed an integrated learning method for language skills and cultural understanding in TISOL. Its focused on learning method that integrated language skills and cultural understanding. The themes of culture such as social, economic, education, and tourism were discussed in this method. They referred to one of the Brown's language principles, language-cultural linkages (Brown, 2007). This was very suitable in the context of Indonesia with about 250 tribes (Dokhi, Siagian, Sukim, Wulansari, Hadi, \& Sambodo, 2016). The diversity in the tribes of the learners was the basis of a multicultural class management method in a learning process (Saddhono, 2017).

The results of the previous studies focused on the development of general cultural materials, integrated learning model and ICT. However, there were limited numbers of studies about developing BIPA's learning models incorporating local cultures with their moral values of speech politeness to be 
found in almost all vernacular languages in Indonesia. These languages were used by 58.95 percent of the whole population in their daily lives (Dokhi et al., 2016). The values of speech politeness in everyday interactions are very important for the people, especially the young generation and also the foreigners learning Bahasa Indonesia. Because, it creates harmony in interaction and reflect the people and the reality of social and culture condition of the contemporary society (Gusnawaty, Yastiana, \& Yassi, 2017). So, the teaching of Bahasa Indonesia to foreigners needs a learning model which internalizes local cultures, especially the moral values of speech politeness. This will, in its turn, facilitate foreign learners to master Bahasa Indonesia more successfully.

Bahasa Indonesia has a variety of differences in its academic and social domains. Academic variety is used when writing scientific works and academic presentations by using standard Bahasa Indonesia (IS), while social variety is used when interacting with the general public using Bahasa Indonesia in local dialects. The learning model of Indonesian as a foreign language which contains local wisdom as a cultural representation, especially politeness markers as a moral value in social interactions, has not been a real interest among researchers and writers of teaching materials.

Through a learning model that integrate culture, specifically its aspects of local politeness markers, it is expected to improve the communicative competence of the foreign learners (Kramsch, 2006; Richards, 2006; Felemban, 2012). Then, the question is what kind of learning model that can improve the competency of linguistic aspects as well as the aspects of local politeness markers that exist in Indonesia in social interactions for foreign learners? An Bahasa Indonesia learning model that can overcome the problems faced by foreign learners and moral value, not only in the presence of cultural differences including those in the speech culture of particular social interactions, but also in linguistic aspects and communicative performance of the foreign students in Indonesian.

In this paper, we tried to present the results of developing an alternative model of teaching Bahasa Indonesia using Intercultural Politeness Learning Model (IPLM). This model can overcome the problems in using local politeness markers in Indonesian that are encountered when interacting with Indonesian people. At the same time, the communicative competence of the foreign students will improve. As stated by Liddicoat, the mastery of the target language culture, including the politeness marker is the main supporting variable in the communicative competence of the language (Liddicoat, 2011). In developing the model, the principles of intercultural learning from Liddicoat \& Kohler (2012) and the Buginese language politeness strategy were used as basic assumptions.

\section{METHODS}

This research was a Research and Development Design which was designed for developing a model of intercultural local politeness learning for foreign speakers. The stages of research included a) Synthesis of intercultural learning theories and concepts of Buginese politeness strategies and relevant studies; b) a need analysis instrument compilation; c) distributing the needs analysis instruments to 25 foreign students randomly selected among Koreans, Americans, Japanese, and Thais in the Makassar region as respondents; d) analysis of the results of the need analysis; e) designing a draft of Bahasa Indonesia learning models for foreign speakers; f) Focus Group Discussion (FGD); g) Fixing and finalizing the model; and h) try out of model. The model experiment was carried 
out among ten foreign speakers in the immigration shelter, KPI Makassar.

The data collection techniques consisted of a) interview and b) questionnaire. The questionnaire was meant to identify the needs of the foreign learners for an Bahasa Indonesia learning model that could improve their academic competencies as well as the competence of social communication with local communities. There were 10 statements developed from the stages of learning activities and materials. The instrument was validated through construct and content validity procedures. The answers were recorded under the 5-item Likert scale. The data from the questionnaire were analysed by using a descriptive statistical technique. The qualitative data from the interview were analysed by using descriptive-qualitative technique by Miles and Huberman which involved a) data collection; b1) data display; b2) data condensation; and c) concluding: drawing/verifying (Miles, Huberman, \& Saldana, 2014). The results of the experimental model testing were analysed by using t-test.

\section{RESULTS AND DISCUSSION Results}

The results of the descriptive analysis of the needs analysis instruments showed that $75 \%$ of the foreign speakers needed learning activities whose stages of learning process involved them optimally. For the aspect of learning materials, 55\% of the foreign speakers needed materials of local politeness markers. This is due to the fact that the oral interactions of Indonesian local communities were heavily influenced by the existing local politeness markers. The foreign speakers thought that the markers were an obstacle in communications with local people because this could be the source of misunderstanding between them.

Based on the results of the needs analysis, the synthesis and analysis of the theory of the intercultural learning and Buginese politeness strategies, the relevant researches and input from the focus group discussion, the researchers developed an Intercultural Local Politeness Learning (ILPL) Model, an alternative model of teaching Indonesian for foreign speakers. This model contained four steps of learning activities namely noticing, comparing, reflecting, and interacting. Every step involved specific activities that stimulated the students to be active speakers of Indonesian. The ILPL model is shown in Figure 1.

\section{Model Description}

This model was developed from Liddicoat's intercultural pedagogy which consisted of four stages: noticing, comparing, reflecting, and interacting. The developing of the model was carried out to the material and activity aspects of each of the stages. The materials under discussion were local cultures containing certain moral values in the social interactions of the people, especially the values of speech act politeness. Meanwhile the activity in each of the stages was basically learnerscentered. The aim of developing the model was to improve the foreign learners' communicative competencies in Bahasa Indonesia. Authentic assessment was applied in the process of evaluation.

The assumptions of the Local Intercultural Politeness Learning Model were: 1) the finding of the moral values of speech act politeness through videos and/or texts was directly meaningful for foreign learners; 2) the learning process by comparing the potential knowledge of the foreign learners about the moral values of their own mother tongues would facilitate the understanding of Bahasa Indonesia as a target language, and 3) the direct use of the target language in the local communities would facilitate and speed up the foreign learners' mastery of communicative competencies in Bahasa Indonesia. 


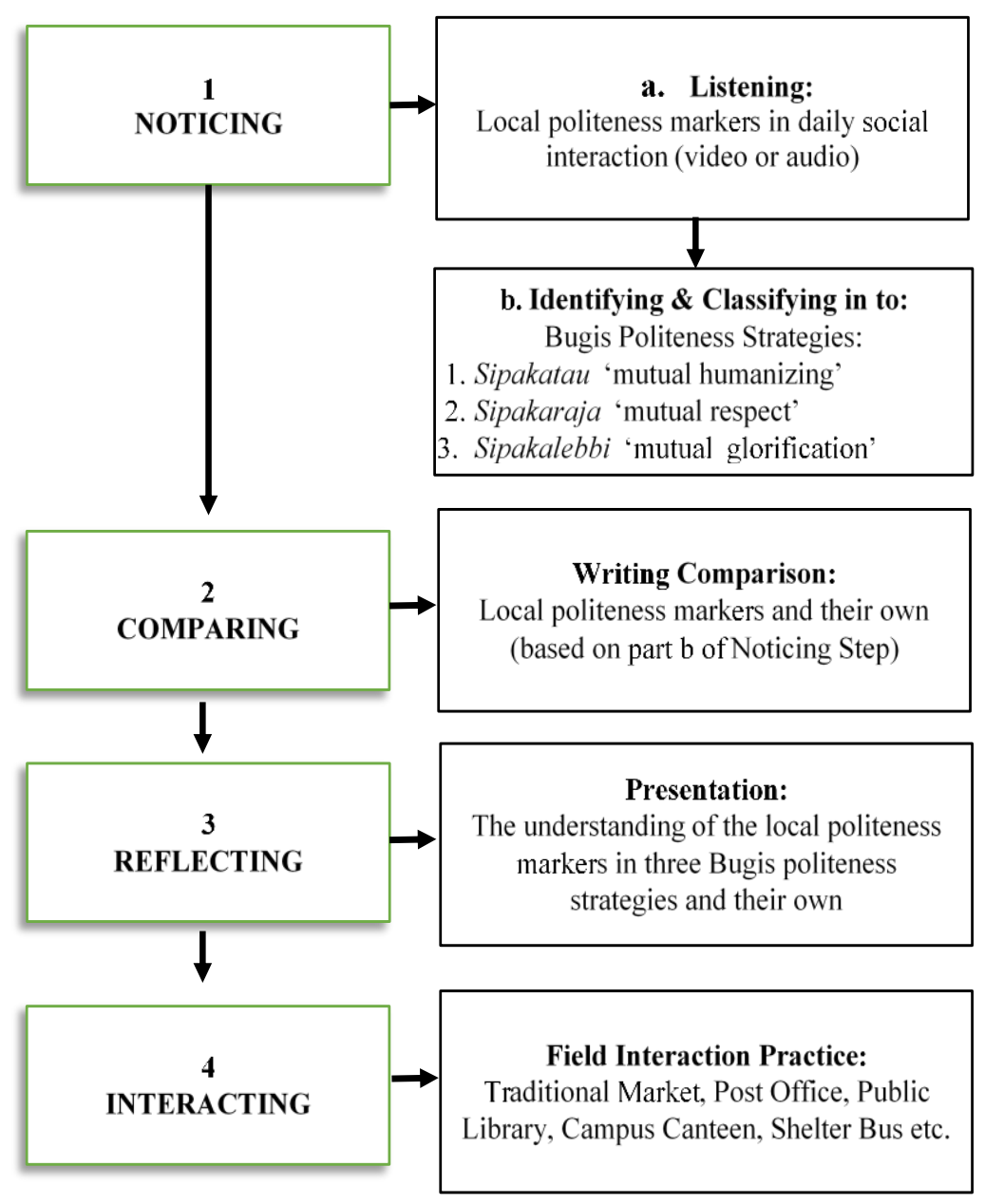

Figure 1. Intercultural Local Politeness Learning (ILPL) Model

\section{Effectiveness of the ILP Model}

The effectiveness of the ILP model was supported by the scores of the pre-test and post-test design of the Somalian, Sudanese, and Ethiopian learners. The tscore was $3.26>$ t-table $=2.45$, signifying that there was a very big difference between the pre-test $\left(\mathrm{X}_{1}\right)$ and post-test $\left(\mathrm{X}_{2}\right)$ results. Besides that, the results of the questionnaires showed the significance of $74.7 \%$ according to the t-test. Based on those results it could be inferred that the local intercultural politeness learning model was effective to improve the foreign learners' communicative competencies.

\section{Discussion}

Bahasa Indonesia has been studied by various foreign speakers for different purposes and reasons in the past few years.
Therefore, the developing of textbooks and methods in learning Indonesian for foreign speakers has been carried out by a growing number of researchers. The learners who were the foreign speakers with different cultural and linguistic backgrounds must be taken into consideration. Consequently, specific cultural materials as an important factor in mastering a foreign language was included in the topic of discussion about both the materials and learning method. However, the cultural elements to be included had something to do with the diversity of traditions, tribes, crafts, and natural beauty. Meanwhile, the local politeness markers as an important part of the local language that existed in the Bahasa Indonesia were not taught properly. In fact, such linguistic features as politeness markers often turned out to be a 
barrier for foreign speakers when interacting with local people. Differences in the variety of Indonesian academic and social language styles could lead to a lack of understanding or even misunderstanding. Thus, the communicative competence of the foreign speakers learning Bahasa Indonesia was not optimally developed.

This study developed an Bahasa Indonesia learning model for foreign speakers based on their need and the concept of intercultural learning and politeness strategies in Buginese culture. The diversity of cultures and the variety of local politeness markers owned by the Indonesian people were used as the framework of this learning model. The mastery of the grammatical rules of Bahasa Indonesia as well as the distinctiveness of local politeness markers would certainly improve the communicative competence of the foreign speakers. This was in line with the opinion of Valeeva \& Valeeva (2017); Liddicoat (2011) in preparing and developing language learners for meaningful communication outside their own cultural environment and a sense of themselves as mediators between languages and cultures.

Intercultural local politeness learning model (ILPLM) consisted of 4 (four) stages of learning activities, namely noticing, comparing, reflecting, and interacting. Each of these stages involved activities that could possibly provide stimulus for the foreign learners to be active in each stage. They would be actively involved in listening, writing comparisons, presenting their selfreflection and interacting directly using Indonesian. This model could overcome the problem of knowledge gaps between the academic language style and that of social which were often encountered by the foreign speakers when interacting with Indonesian local society.

\section{Noticing Phase}

Noticing stage was the learning of the moral values of Indonesian local cultures. As learning in schools needs to understand cultural values, both as material content and learning approaches (Ghufron, Budiningsih, \& Hidayati, 2017). In this phase, politeness as the moral values in social interactions were provided to the foreign learners in the forms of videos, audios, and texts. Noticing involvement was part of learning fundamentals (Liddicoat, 2011). The purpose of such an activity was to make the learners notice certain cultural similarities and differences and their significance for the foreign learners. Then, they were supposed to gather the cultural similarities and differences by using the target language as a central element of intercultural learning. When they got new experiences, the learners needed to examine the new information in their own terms and tried to understand what it was that they really experienced. Noticing, however, was not necessarily a naturally occurring activity for the learners in the classroom. Rather, it was an activity that occurred in a framework of understandings that regulated what could and should be noticed (Liddicoat, 2011).

The materials of the noticing stage were politeness markers. The stage began with an introduction to the local politeness strategies that existed in Indonesian society, especially those in South Sulawesi. There were three strategies of politeness in the Buginese community which could be identified through the local politeness markers used by the native speakers. In his study Pelras found that Buginese society was one of the most complex and apparently rigidly hierarchical of all the tribes in the archipelago, with a distinctive strata comprising several degrees of "mobility" (Pelras, 2006). The hierarchy influenced the way the Buginese spoke. 
The Buginese community has a concept of sipakatau 'mutual humanizing', sipakaraja 'mutual respect', and sipakalebbi 'mutual glorification' in their interactions. Sipakatau 'mutual humanizing' is a general basis of all aspects of life in the interaction of Buginese people in both formal and informal situations, with both younger and older partners, and among both the same and different social status. All the interactions are carried out within the same social status or sitinaja which means "appropriate, reasonable, fulfilling, and not excessive".

The next strategy of sipakaraja 'mutual respect' is an additional ethic in social interaction by considering who, when, where and what to be discussed. In other words, sipakaraja is the way of speaking that shows the speaker's knowledge of the world. The speaker understands what and how to say something to anyone in both formal and informal situations. The person who implements sipakaraja is called taumakkeade which means people who keep their ethical manners.

The last strategy, sipakalebbi 'mutual glorification' is the highest conduct of all interactions among the Buginese society. The intended behavior includes verbal and non-verbal actions. The strategy of sipakalebbi is usually used in formal situations of such cultural ritual activities and special events like dowry surrender events, cleaning up local heritage and so on. The characteristics of language politeness which are often used in this kind of interactions include the use of the highest respect toward the interlocutor. All these strategies are illustrated in the Figure 2.

The scheme of the Buginese politeness strategies in social interactions above is in line with Angela Hobjila's statement that communication as interaction involving the relationship, report and permanent adaptation to the others, of the acts in a specific communication situation (Hobjilă, 2012). In such a situation, there are four variables including the positive and negative face of the speaker, and the positive and negative face of the interlocutor. However, the results of the dynamics of interaction can be "threatened" in the act of communication. That is why the politeness strategies need to be updated in order to counteract/redress the acts which can be menacing for one or more of the faces of the speaker/ the interlocutor (Hobjilă, 2012).

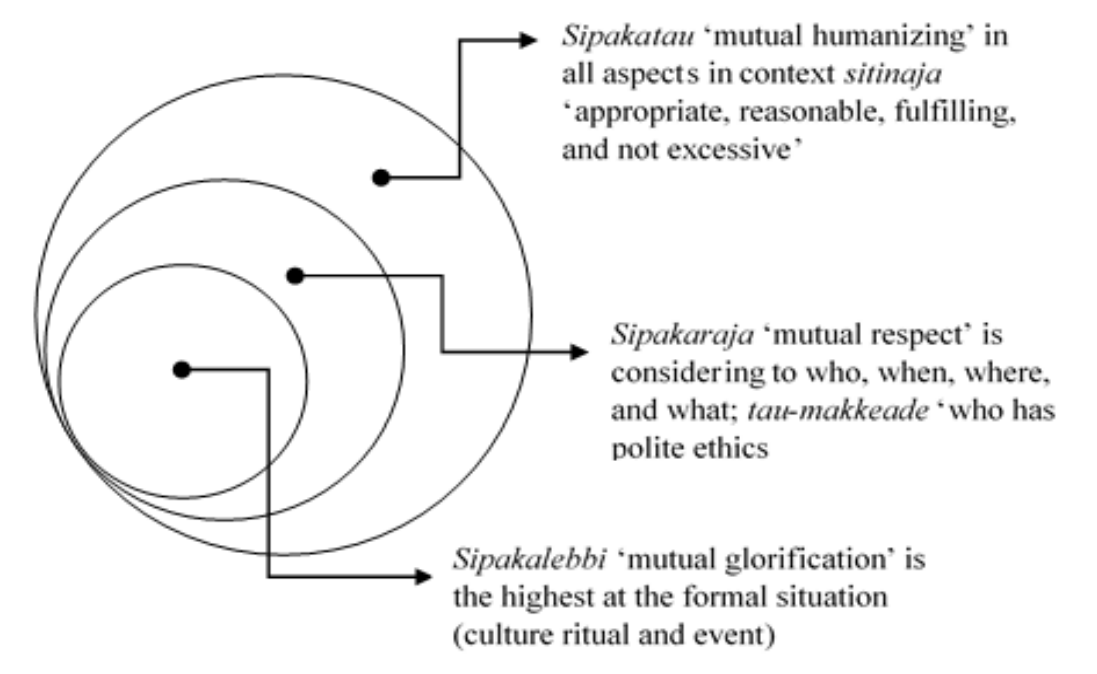

Figure 2. Buginese Politeness Strategies in Social Interaction Context 
The Buginese politeness markers frequently used in Bahasa Indonesia structure are address terms, politeness formula, and deixis. The address terms are puang and ndi.

Example 1: A driver asks his passenger.

1. Driver with : "Dimanaki mau diantar IBD Puang?"

IS : :Dimana alamatnya Pak/Ibu?"

: "Where is the address, sir?"

Passengger : "Tabe, saya diantar ke with IBD terminal saja Ndi."

IS : "Tolong, antar saya ke terminal, dik."

: "Please, take me to the bus station, brother."

The address term puang that is used by the driver in sentence 1 reflects respect and politeness toward his passenger. On the other hand, the passenger replies in a polite way, too. The passenger responds by using the address term ndi implying a respectful and polite speech act although he is a Buginese noble and a lecturer who is socially higher in rank.

Secondly, the politeness formula iyek 'yes' and tabek 'excuse me'. The word iyek is very often used in interacting with Buginese people. The word iyek is not only used to show an agreement but also to indicate a polite attitude in an interaction.

Example 2: In a formal context at the library. The conversation happens between a student and a librarian.
2a. Librarian with IBD : "Mau semua kita pinjam buku ini?"
IS

$$
\begin{array}{ll}
\text { Student with IBD } & \text { : "Iyek, Puang." } \\
\text { IS } & \text { : "Iya, Pak/Ibu!" } \\
& \text { :"Yes, Sir." }
\end{array}
$$

The use of the word tabek 'excuse me' in an informal situation at the campus canteen.
2b. Waitres with : "Tabek, pesan apaki, IBD ndi."
IS : "Maaf, Anda pesan apa?"
: "Excuse me, your order, please?"
Consumen : "Mie ayam, minumnya air with IBD hangat."
IS : "Saya pesan semangkok mie ayam dan segelas air hangat."
: "A bowl of chicken noodle and a glass of warm water, please."

Thirdly, deixis. In Buginese language the deixis related with politeness markers is a morpheme that refers to second singular person which has a meaning of possessive pronoun, enclitic and proclitic. The use of deixis in line 2 of Table 1 in the interaction indicates that the speaker respects his interlocutor. While deixis in line 3 signifies the familiarity between the speaker and the interlocutor. This is in line with Levinson's statement that politeness in speaking can be observed from the use of social deixis showing solidarity of speakers and hearers (Levinson, 1979). Moreover, social deixis is described as "a reference to the social characteristics of, or distinctions between, the participants or referents in a speech event" (Levinson, 1979). Therefore, a deixis indicates both distance and

\begin{tabular}{|c|c|c|c|c|c|c|}
\hline No & Meaning & Possesive & Pronoun & $\begin{array}{l}\text { Enclitic } \\
\text { (/absolutive) }\end{array}$ & $\begin{array}{l}\text { Proclitic } \\
\text { (/ergative) }\end{array}$ & Deixis \\
\hline 1 & Saya/ku & $\begin{array}{l}-k u \\
-e(h)\end{array}$ & Iya' & $-\mathrm{ka}$ & $\mathrm{u}-/ \mathrm{ku}-$ & First person \\
\hline 2 & Anda & $-\mathrm{ta}$ & Idi’ & $-\mathrm{ki}$ & ta- & $\begin{array}{l}\text { Second person, } \\
\text { inclusive/honorific }\end{array}$ \\
\hline 3 & $\mathrm{Kamu} / \mathrm{mu}$ & $-\mathrm{mu}$ & Iko & -ko & mu- & Second person, familiar \\
\hline 4 & Dia/nya & -na & -- & $-\mathrm{i}$ & na- & Third person \\
\hline
\end{tabular}
viewpoint of the speaker and the hearer.

Table 1. Deixies in Buginese Politeness 
Example 3: The deixis in line 2 above is used in an informal context in the waiting room of a post office. A young man has a conversation with another young man sitting next to him.

3a. Man A : "Mauki kirim surat kemana?" with IBD

IS : "Anda mau mengirim surat ke mana?"

: "To whom is your letter sent?"

Man B : "Kepada adikku, di Jakarta." with IBD

IS : "Saya mau mengirimnya kepada adik saya di Jakarta."

: "I am sending it to my brother in Jakarta."

Man B : "Idi', mauki kirim apa?"

with IBD

IS : "Anda sendiri akan mengirim apa?"

: "What about you? What are you sending?"

Man A : "Mauka kirim paket untuk with IBD kakakku di Semarang."

: "I am sending this package to my older brother in Semarang."

3b. Context: In the classroom, between a Manado and Buginese. A Manado is looking for his pen.

\begin{tabular}{|c|c|}
\hline $\begin{array}{l}\text { Manado with } \\
\text { IMD }\end{array}$ & :"Ini Kita pe polpen?" \\
\hline IS & $\begin{array}{l}\text { : “Ini polpen milik saya?” } \\
\text { : “Apakah ini polpen saya } \\
\text { : “Is this my pen?” }\end{array}$ \\
\hline $\begin{array}{c}\text { Buginese with } \\
\text { IBD }\end{array}$ & $\begin{array}{l}\text { : "Bukan, ini Kita' punya } \\
\text { polpen." }\end{array}$ \\
\hline IS & $\begin{array}{l}\text { :"Bukan, ini polpen milik } \\
\text { anda." } \\
\text { :"No, this is your pen." }\end{array}$ \\
\hline
\end{tabular}

The Manado began to get angry, because he thought the Buginese recognized his pen as his own.

\begin{tabular}{|c|c|}
\hline Manado with & : "Heh! Ini bukan ngana pe \\
\hline IMD & polpen, ini Kita punya." \\
\hline IS & $\begin{array}{l}\text { : "Heh!, Ini bukan polpen } \\
\text { milik Anda, ini milik saya." } \\
\text { :"Hah!, This is not your pen, } \\
\text { this is mine." }\end{array}$ \\
\hline $\begin{array}{c}\text { Buginese with } \\
\text { IBD }\end{array}$ & : “Iya, itu kita’ punya.” \\
\hline & aya." \\
\hline
\end{tabular}

In fact, the Buginese says that the pen is not his, but belongs to the Manado. The problem is the use of the word kita which belongs to different types of words and meanings. Kita as a second person in Buginese politeness marker, means 'you or yours.' This is in contrary with the Manado. In North Sulawesi the word kita is used as a first person pronoun singular, meaning ' $I$ or mine' and it is not a politeness marker. The meanings are very different. Therefore, the foreign learners should understand this well because this can arise a misunderstanding and, even, conflict between a speaker and his interlocutor as illustrated in the example above.

Example 4: The use of deixis in line 3 above happens in an informal context between two students who have been friends since high school in the parking lot

$$
\begin{aligned}
& \text { 4. Student } 1 \text { : "Hey, mauko pulang ke } \\
& \text { with IBD asrama?" } \\
& \text { IS : "Hey, Kamu mau pulang ke } \\
& \text { asrama?" } \\
& \text { : "Are you going to the } \\
& \text { dormitory?" } \\
& \text { Student } 2 \text { : “Iyyo, mauka”. "Iko?" } \\
& \text { with IBD } \\
& \text { IS : "Iya, Saya mau pulang". } \\
& \text { "Kamu?" } \\
& \text { : "Yes, I am. You?" } \\
& \text { Student } 1 \text { : "Mauka ke kantor pos." } \\
& \text { with IBD } \\
& \text { IS } \\
& \begin{array}{l}
\text { : "Saya mau pergi ke kantor } \\
\text { pos." } \\
\text { :"I will go to the post office." }
\end{array}
\end{aligned}
$$

The politeness meaning in the sentences above can be explained as follows. The deixis $i d i$ 'you' in example $3 \mathrm{a}$ and $i k o$ 'you' in example 4 are the second forms of personal pronouns that show respect and politeness. Idi is usually used for asking questions or asking for confirmation to newly aquainted people and older or respected people. While iko is usually used for people of the same age, people who are familiar, younger people and commoners. The expressions of $-k i$ and -ko 'you' are used to greet the second person functioning as enclitic. The word - 
$k i$ is usually used for older people or newly acquainted people and those with higher social status, while the word $-k o$ is used in the same way as $i k o$. The forms of $-k i$ and $k o$ are inclusive, meaning that those personal pronouns refer to the speaker and the listener or interlocutor. This second personal pronoun is used in imperative sentences which state commands or invitations as well as interrogative sentences.

The use of deixis in line 2 including the address terms puang and $n d i$ and the formula iyek and tabek in vernacular people's interactions in South Sulawesi is a form of simultaneous implementations of the strategies sipakatau 'mutual humanizing', sipakaraja 'mutual respect' dan sipakalebbi 'mutual glorification'. Meanwhile, the use of deixis in line 3 and the formula iyyo is a form of implementation of the strategy sipakatau 'mutual humanizing' by considering the who, when, where and topics to be discussed as a guide in choosing certain Buginese politeness markers.

The description above shows that the noticing stage provides a good environment for foreign learners to understand Buginese politeness markers used in Bahasa Indonesia. Therefore, as it stated by Aylward this phase stimulates the learner to rediscover existing knowledge and skills as well as opening doors into new discoveries (Aylward, 2012). Noticing phase provides adequate, appropriate and relevant learning materials to the learners for their own knowledgeschemata in preparation for using Bahasa Indonesia in real interactions and conducting comparisons with their native languages.

\section{Comparing Phase}

Comparing, the second phase in ILPL model is writing activity in Bahasa Indonesia among the foreign learners. At this stage, the foreign learners write similarities and differences in politeness identified from the video, audio and/or text with those in their native languages. This process motivates the foreign learners to use all their potential knowledge, insights and skills to communicate in Indonesian written texts. In line with Liddicoat's opinion, the comparing process is multilayered, which requires space not only to compare the background of foreign learner culture with that of the target language but also between the knowledge of the target language they have acquired and the new cultural knowledge they obtained during the noticing phase (Liddicoat, 2011).

In a global context, comparing activities provide opportunities for the foreign learners to learn Bahasa Indonesia as well as their own language. Discussions about the similarities and differences in the peculiarities of the spoken language will enhance the understanding and mastery of the target language, Bahasa Indonesia. This is due to the process of learning Bahasa Indonesia by using their language knowledge as a comparison. This is supported by the opinion of Kohonen (Liddicoat, 2011) that comparison of similarities and differences provide a resource for reflection and reflection as a classroom process is a core element of developing interculturally.

\section{Reflection Phase}

Reflection, the third phase requires the foreign learners not only to present their conclusions or opinions about the materials being studied but more importantly to show their personal attitudes based on their experience. In line with this John Dewey stated cited in Pacheco that to reflect is to look back over what has been done so as to extract the net meanings, which are the capital stock for intelligent dealing with further experiences. It is the heart of intellectual organization and of the disciplined mind (Pacheco, 2011). 
The personal attitudes of the foreign students is presented in the class, then their classmates respond. Discussions that occur can train the foreign learners to use Bahasa Indonesia and develop their own cultural sensitivity as well. In the end, through this reflection phase, the foreign learners will improve their Bahasa Indonesia competence and simultaneously develop the awareness of the diversity in marking local politeness that exists in social interactions. Liddicoat called this phase as reflecting on what one's experience of linguistic and cultural diversity for oneself, how he reacts, thinks, and feels about diversity, and will find ways of engaging constructively with the diversity (Liddicoat, 2011). Thus, after completing this third stage, the foreign students acquire both Indonesian linguistic competence and its accompanying elements of politeness markers. Moreover, the foreign students develop a personal attitude and awareness towards the three Buginese politeness strategies (sipakatau, sipakaraja, and sipakalebbi) which are the basis of Indonesian society, especially the people of South Sulawesi in their daily interactions.

\section{Interacting Phase}

In this phase the foreign learners are asked to interact directly with the community. The location can be in the market, campus canteen, campus library, campus environment, post office, and so on. They will practice the materials of local politeness markers that they have learned before. The practices carried out in real interactions will increase the opportunities of the foreign learners practicing Bahasa Indonesia. This activity will improve their Bahasa Indonesia competence specifically their fluency and mastery of local politeness markers from different locations. It is assumed that the foreign students will not meet any problem about the local politeness markers in Bahasa Indonesia used by the community because they have learned such markers in the previous three phases.

The marking of local language politeness as part of local culture was not specifically taught. The linguistic politeness markers such as greeting words, honorifics, decisive particles, hedges and so on are very important because they will be encountered by foreign students in social interaction when they speak to Indonesian people, for example (a) mau pergi ke mana?, nggak mampir dulu 'Where are you going? Don't stop by first?' (Asmara, 2015); (b) Maaf, barangkali bisa bapelan sadiki leh. Tabek leh, 'Excuse me, could you be more slowly. please?' (Saddhono \& Fatma, 2010); (c) Kapan-ki datang? 'When did you come?'; (d) Kita mau ke mana? 'Where are you going?

The statement in sentence (a) above is often heard in Javanese society as Indonesian Javanese dialect (IJD) especially in non-formal situations but is not acceptable in formal situations. The sentence shows the hospitality towards the interlocutor. On the other hand, for foreign speakers this is deemed impolite because the matter in question is considered a private matter (Andayani, 2016). This cultural difference, especially in daily conversations, is one of the problems faced by foreign speakers (Bagus et al., 2017).

Furthermore, sentence (b) displays two markers of politeness which are a combination of Indonesian Manado dialect (IMD) and Indonesian Buginese dialect (IBD). Those particles namely leh after the word sadiki from the Manado language and the word tabek as a honor in the Buginese language. Furthermore (c and d) are Bahasa Indonesia in Buginese dialect. $\boldsymbol{k i}$ 'you-HON' and word kita 'you-Incl' usually used by Buginese speakers in greeting people who have just arrived or been met. This is applied to both Indonesians and foreigners. This is the way the Buginese show their politeness toward their interlocutors. This kind of 
language phenomenon will be encountered by foreign students in their interactions with Indonesian society. Politeness markers are very important to be considered because they are used in speaking to avoid possible conflicts. Brown and Levinson argue that every speech has the potential to cause conflict (Brown \& Levinson, 1987). Therefore, politeness in speaking is a manifestation of speech strategy so the speaker's meaning can be conveyed without threatening face (of the speaker or the hearer). It is also a realization of communication strategy (Mills, 2003).

The interactions provide three learning aspects simultaneously for the foreign learners namely speakers, interlocutor and context. Fortunately, context is very influential to the mastery of communicative competence among the foreign speakers. As described in the background, different contexts will require different communication skills, especially in terms of local politeness markers choices. How can the word kita give a different meaning just because it is pronounced in a different context (as illustrated in case of Manado and Buginese people in the noticing phase). Therefore, an observation record sheet is provided with several items to be filled. There is a column for the location, time, topic of discussion, gender, age, occupation, identified local manners, length of time of speaking. All these pieces of information function as a reference for the foreign students in compiling the Buginese politeness strategy categories used by local speakers and interlocutors.

In the context of language learning, an interaction is an important technique to improve language competence. Mackey stated that the more you interact the more successful your second language development is (Lobatón, 2011). Therefore, the interaction phase in the ILPL model is very suitable to facilitate the opportunity for the foreign learners to use Bahasa Indonesia in direct interactions with local community members. Through such regular direct interactions with those people, the communicative competence of the foreign speakers develops.

This ILPL model was based on the results of the foreign speakers' need analysis of the Bahasa Indonesia and the synthesis of the theory of intercultural learning, Buginese politeness strategies and relevant researches. This model involved four phases. Supported by several foreign language learning theories, the four phases of the ILPL model can maximally elaborate the linguistic potentials of the foreign learners about the materials of marking local politeness. However, the model was not used yet at the other region because this research was limited time. Therefore, further researches can use the model through a quasiexperimental research and the like.

\section{CONCLUSION}

Intercultural Local Politeness Learning Model (ILPLM) is a Bahasa Indonesia learning model for foreign learners consisting of two important parts, namely the phase to activate the students and the materials of local politeness markers. The phase consisted of noticing, comparing, reflecting, and interacting which stimulated the foreign learners to be active in the materials exploration process. In the learning material section, the local politeness markers in the three Buginese politeness strategies were discussed then compared to those in their native languages. Based on these activities in the two parts, the ILPL model was believed to improve the Bahasa Indonesia communicative competence among the foreign learners and develop an awareness and understanding of the importance of known local politeness markers because they could facilitate communications and avoid misunderstandings while interacting.

Therefore, the ILPL model is recommended for use in Bahasa Indonesia 
teaching programs for foreign speakers. Through this implementation, the effectiveness grade of the model in improving the communicative competence of Bahasa Indonesia among the foreign learners could be assessed.

\section{ACKNOWLEDGEMENTS}

We would like to express our deepest thanks to the committee of the LATU International Conference 2018, Thammasat University Thailand, rector of Hasanuddin University, and rector of State Islamic Institute Sultan Amai Gorontalo who gave us the opportunity and funded us to present this article.

\section{REFERENCES}

Andayani. (2016). Improving the language skills and local cultural understanding with integrative learning in Teaching Indonesian to Speakers of Other Languages (TISOL). International Journal of Language and Linguistics, 3(2), 44-53.

Asmara, R. (2015). Basa-basi dalam percakapan kolokial Berbahasa Jawa sebagai penanda karakter santun berbahasa. Jurnal Transformatika, 11(2), 80-95. doi: 10.31002/transformatika.v11i2.2 15 .

Aylward, R. (2012). The three phases of learning. IPEDR, 47(7), 32-36. doi: 10.7763/IPEDR.

Bagus, I., Mantra, N., Ayu, I., Sri, M., \& Author, C. (2017). Developing learning methods of Indonesian as a foreign language. International Journal of Social Sciences and Humanities, 1(2), 51-57. doi: 10.21744/ijssh.v1i2.41.

Brown, P. \& Levinson, S. C. (1987). Politeness: Some universals in language usage. Cambridge:
Cambridge University Press.

Brown, H. D. (2007). Teaching by principles an interactive approach to language pedagogy. New York, NY: Longman.

Dokhi, M., Siagian, T. H., Sukim, Wulansari, I. Y., Hadi, D. W., \& Sambodo, N. (2016). Analisis kearifan lokal ditinjau dari keragaman budaya. Jakarta: PDSPK Kemendikbud RI.

Felemban, F. H. (2012). Building up learners' communicative competence: The politeness principle. Procedia Social and Behavioral Sciences, 46(1894), 70-76. doi: 10.1016/j.sbspro.2012.05.070.

Ghufron, A., Budiningsih, C. A., \& Hidayati. (2017). Pengembangan pembelajaran berbasis nilai-nilai budaya Yogyakarta di sekolah dasar. Cakrawala Pendidikan, 36(2), 309319. doi: 10.21831/cp.v36i2.12449.

Gusnawaty, G., Yastiana, Y., \& Yassi, A. H. (2017). Ideational meaning of butonese foklore: A systemic functional linguistics study. Rupkatha Journal on Interdisciplinary Studies in Humanities, IX(1), 327-338. doi: 10.21659/rupkatha.v9n1.33.

Hobjilă, A. (2012). Positive politeness and negative politeness in didactic communication-landmarks in teaching methodology. Procedia Social and Behavioral Sciences, 63, 213-222. doi: 10.1016/j.sbspro.2012.10.032.

Karim, S. A. (2015). Developing an indonesian textbook for non-native learners of indonesian at elementary. Indonesian Journal of English Language Teaching, 10(2), 52-68. 
Kramsch, C. (2006). From communicative competence to symbolic competence. The Modern Language Journal, 90(2), 249-252. doi: 10.1111/j.15404781.2006.00395_3.x.

Kusmiatun, A. (2016). Topik pilihan mahasiswa Tiongkok dalam pembelajaran BIPA program transfer kredit di UNY. Litera, 15(1), 138146. doi: 10.21831/ltr.v15i1.9773.

Levinson, S. C. (1979). Pragmatics and social deixis: Reclaiming the notion of conventional implicature. Proceedings of the Fifth Annual Meeting of the Berkeley Linguistics Society, 206-223. doi: 10.3765/bls.v5i0.2162.

Liddicoat, A. J. (2011). Language teaching and learning from an intercultural perspective. In E. Hinkel (Ed.), Handbook of research in second language teaching and learning (Second). New York, NY: Routledge.

Liddicoat, A. J., \& Kohler, M. (2012). Teaching Asian languages from an intercultural perspective: Building bdigdes for wth students of Indonesia. In X. Song \& K. Cadman (Eds.), Bdidgung Transcultural Divides. New Wales: University of Adelaide Press.

Lobatón, J. C. G. (2011). Peer interaction: A social perspective towards the development of foreign language learning. Profile, 13(1), 189-203. Retrieved from https://revistas.unal.edu.co/.

Megawati, C. (2014). Pengembangan media pembelajaran BIPA tingkat menengah melalui e-book interaktif di program incountry Universitas Negeri Malang Tahun 2014. Jurnal Nosi, 2(1), 62-70.

Miles, M. B., Huberman, A. M., \&
Saldana, J. (2014). Qualitative data analysis a methods sourcebook (3rd ed.). Los Angales: Sage.

Mills, S. (2003). Gender and politeness. Cambridge: Cambridge Umniversity.

Nurgiyantoro, B. (2010). Sastra anak dan pembentukan karakter. Cakrawala Pendidikan, 1(3), 25-40. doi: 10.21831/cp.v1i3.232.

Nurhuda, T. A., Waluyo, H. J., \& Suyitno. (2017). Pemanfaatan sastra sebagai bahasa ajar pengajaran BIPA. Proceedings Education and Language International Conference, 864-869. Unissula.

Pelras, C. (2006). Manusia Bugis (A. R. Abu, Hasriadi, dan N. Sirimorok Trans.). Jakarta: Nalar.

Pacheco, A. Q. (2011). Reflective teaching and its impact on foreign language teaching. Actualidades Investigativas En Educación, 5(3), 1-19. doi: 10.15517/aie.v5i3.9166.

Richards, J. C. (2006). Communicative language teaching today: Language teaching (Vol. 25). Cambridge: Cambridge University Press. doi: 10.2307/3587463.

RoI, Law 2009 No. 24, Bendera, Bahasa, dan Lambang Negara, serta Lagu Kebangsaan Flags, Languages, and National Symbols, with the National Anthem.

Saddhono, K. (2017). Manajemen kelas multikultural dalam pembelajaran Bahasa Indonresia bagi Penutur Asing (BIPA) di Indonesia. Conference on Language and Language Teaching, 561-567.

Saddhono, K., \& Fatma. (2010). Bentuk dan fungsi bahasa lokal dalam tindak 
tutur direktif pada lingkungan perguruan tinggi di Sulawesi Tengah, 18(12), 1977-1985.

Sari, N. P. A. W., Sutama, I. M., \& Utama, I. D. G. B. (2016). Pembelajaran Bahasa Indonesia Bagi Penutur Asing (BIPA) di sekolah cinta bahasa, Ubud Bali. E-Journal Prodi Bahasa Dan Sastra Indonesia, Undiksha, 5(3).
Sudini, L. P. (2008). Peranan Visa On Arrival (VOA) bagi orang asing yang datang ke Indonesia. Jurnal Hukum Dan Pembangunan, 38(3), 335-352.

Valeeva, R., \& Valeeva, A. (2017). Intercultural education from Russian researches perspective. Procedia Social and Behavioral Sciences, 237(June 2016), 1564-1571. doi: 10.1016/j.sbspro.2017.02.246. 